\title{
Open defecation and squat toilets, an overlooked risk of fecal transmission of COVID-19 and other pathogens in developing communities
}

\author{
Shiyi Sun ${ }^{1} \cdot J^{2} \operatorname{Han}^{1}(\mathbb{D}$
}

Received: 4 November 2020 / Accepted: 17 November 2020 / Published online: 29 November 2020

(c) Springer Nature Switzerland AG 2020

\begin{abstract}
The novel coronavirus disease COVID-19 has infected over 46 million people in 219 countries and territories. Following evidence of viral loadings and infectivity of feces of infected individuals, public health authorities have suggested to take precautions on the transmission of COVID-19 via fecal-associated routes. Recent discussions on fecal transmission of COVID-19 have mainly focused on municipal sewage. Yet, a widely neglected aspect in containing the virus is that a major part of the population in developing regions do not have access to private, clean sanitary facilities. Therefore, we hypothesize that open defecation and the prevalent use of squat toilets are additional risk factors in those communities. Here, we review fecal transmission of COVID-19, the practices of open defecation, and the resultant routes of transmission of fecal pathogens. Also, we highlight the open design of common squat toilets and the potential exposure to fecal droplets and residues. We observed that at least 20 countries reporting more than 10,000 confirmed infections have 5-26\% of their population practicing open defecation. We illustrate the potential routes of transmission of COVID-19 and other fecal pathogens via human feces in communities practicing open defecation. Here, poor hand hygiene, contaminated shoes and objects, mechanical vectors, and outdoor human activities can all contribute to fecal transmission. Other risk factors include squat pans with lidless designs and open flushing mechanisms, in-cubicle open waste bins, and the lack of water-sealing U-traps in squat toilets.
\end{abstract}

Keywords Coronavirus $\cdot$ SARS-CoV-2 $\cdot$ Infectious agent $\cdot$ Feces $\cdot$ Sanitary $\cdot$ Hygiene

\section{Introduction}

The global outbreak of the coronavirus disease 2019 (COVID-19) caused by severe acute respiratory syndrome coronavirus 2 (SARS-CoV-2) is rapidly sweeping across the world, which has caused over 46.5 million confirmed cases including more than 1.2 million deaths as of November 3, 2020 (WHO 2020a). The pandemic has impacts on numerous aspects of the natural environment and human society, such as air quality (Wang et al. 2020a; Paital and Agrawal 2020), human behaviors (Han and He 2020; Han et al. 2020; Sun and Han 2020; Wang et al. 2020b), and vaccine acceptance (Dai et al. 2020). Particularly, the ongoing pandemic

Jie Han

jiehan@xjtu.edu.cn

1 Department of Environmental Science and Engineering, Xi' an Jiaotong University, Xi' an 710049,

People's Republic of China is posing significant challenges to infrastructures, including sanitation facilities, especially in developing communities (Sun and Han 2020; Usman et al. 2020). With over eight million confirmed cases and persisting high numbers of new daily infections, India has become the second epicenter of the COVID-19 pandemic, after the USA (WHO 2020a).

SARS-CoV-2 is primarily transmitted between people via respiratory droplets, contact routes (WHO 2020b), and aerosols (Sharma et al. 2020; Morawska and Milton 2020; Setti et al. 2020). Governments and regulatory bodies have issued guidance and mandates to reduce virus spread via these recognized routes. Fecal transmission, however, remains a less recognized and under-investigated route in community environments, although ample evidence has shown the prolonged shedding of SARS-CoV-2 in the feces of asymptomatic, pre-symptomatic, and convalescent individuals, with substantial viral loads and proved infectivity under common ambient conditions (Gu et al. 2020; Jeong et al. 2020; Olusola-Makinde and Reuben 2020; Sun et al. 2020; Xiao et al. 2020). Community-acquired infection, outbreak, and 
superspreading event have been caused by inadequate practices on the sanitary disposal of human wastes during the current pandemic (IOGMPG 2020; PGBM 2020) and during the 2003 SARS epidemic (Yu et al. 2004). A multitude of fecal-associated transmission modes such as fecal-oral, fecal-respiratory, and fecal-fomite could result from inadvertent exposure to virus-laden human excreta (Heller et al. 2020). In the latest public guidance, the World Health Organization (WHO 2020c) highlighted the importance of safely managing human sanitary wastes, which included the prevention of aerosolized fecal matter, fecal contamination on hands, and fecal sludge management during the current pandemic. The WHO interim guidance also suggested that, where possible, individual toilet or latrine should be provided to suspected or confirmed individuals to reduce the risks of COVID-19 infection via human fecal matter.

In developing communities, access to clean and private sanitary facilities can be difficult for a significant portion of the population, and gaps remain in the present day in their infrastructures on human waste management. A 2019 joint report issued by the United Nation Children's Fund (UNICEF) and the WHO showed that, around the globe, there were 673 million people still defecating in the open, and 1.3 billion people had to make use of limited (i.e., sharing improved sanitation facilities with other households) or unimproved sanitation facilities (UNICEF and WHO 2019). Most of those communities were located in developing countries across Asia and Africa. An even wider risk factor, however, lies in the design of the toilets in these communities. Unlike the closestools often found in western homes, open-flushing squat toilets are extremely common in countries in southeast Asia, central America, and Africa. The lidless design and open flushing mechanism could easily expose users to fecal droplets and residues, posing additional risks of virus transmission in public toilets and those shared between different households in the current pandemic. While public education and emergency orders may help reduce the practices of open defecation during COVID-19, these open squat toilets constitute an essential part of the existing sanitary infrastructure in these communities, which cannot be upgraded or replaced in the near term. Driven by socioeconomic and cultural factors, these longstanding gaps may become significant obstacles in current efforts on preventing fecal transmission of COVID-19 in these communities (Fig. 1).

In this work, we highlight these longstanding issues by focusing on open defecation and squat toilets, both as probable but neglected sources of fecal-associated transmission of the novel coronavirus in these communities. Specifically, our discussions mainly involve the following: (1) the global situation of open defecation, associated mitigation measures, and difficulties in eliminating such practices, (2) elevated risks of fecal transmission of COVID-19 and potential transmission routes in communities practicing open defecation, (3) issues in the general design and flushing mechanism of squat toilets that are commonly used in developing communities in the COVID-19 context, (4) increased risks and transmission modes of COVID-19 and other fecal pathogens in squat toilets.

\section{Open defecation poses elevated risks of fecal transmission of COVID-19}

By leaving human excreta fully exposed in the environment, open defecation has been a persistent contributor to life-threatening diarrhea, respiratory diseases, parasitic worm infections, and childhood stunting (WHO 2019). WHO declared that approximately 525,000 children under five were killed by diarrhea each year, and open defecation played a dominating role in this (WHO 2017a). The unsanitary practice and unmanaged human wastes can facilitate the spread of COVID-19 in these communities, where various transmission modes could be effectuated (Fig. 2). Since the onset of the COVID-19 pandemic, there have been at least 20 countries reporting significant numbers of COVID-19 infections $(>10,000)$ while also having a significant portion of their population (5-26\%) conventionally practicing open defecation (Fig. 3). A number of risk factors may arise from such practices. First, it is hard to see that people can maintain proper hand hygiene after practicing open defecation (Caruso and Freeman 2020). Also, contamination of shoes, feet, hands, and items intended for human contact may occur during human activities in outdoor environments where people have defecated in the proximity. Mechanical vectors such as flies, cockroaches, beetles, rabbits, domestic dogs, and other coprophagous species could be easily attracted and approach human feces defecated in the open, which can subsequently contaminate food and surfaces that people may contact (Dehghani and Kassiri 2020; Heller et al. 2020). Further, open defecation is also a known source of water contamination in places where people defecate into or near open water bodies (WHO 2019). Human excreta enter nearby water bodies via direct dropping or runoffs which then become a source of pathogens for unwarned individuals who may be exposed to contaminated water via inhalation, e.g., virus-laden aerosols, or contact during washing or recreational activities. A further suspected link between open defecation and COVID-19 is that people who lived with diarrhea, malnourishment, stunting, and other diseases that can be spread by open defecation may be more vulnerable to COVID-19 infection or symptom aggravation due to their existing conditions (Guerrant et al. 2013; Rytter et al. 2014; Stewart et al. 2013).

Regulatory bodies and international aid organizations have historically taken efforts to address the deficiencies 

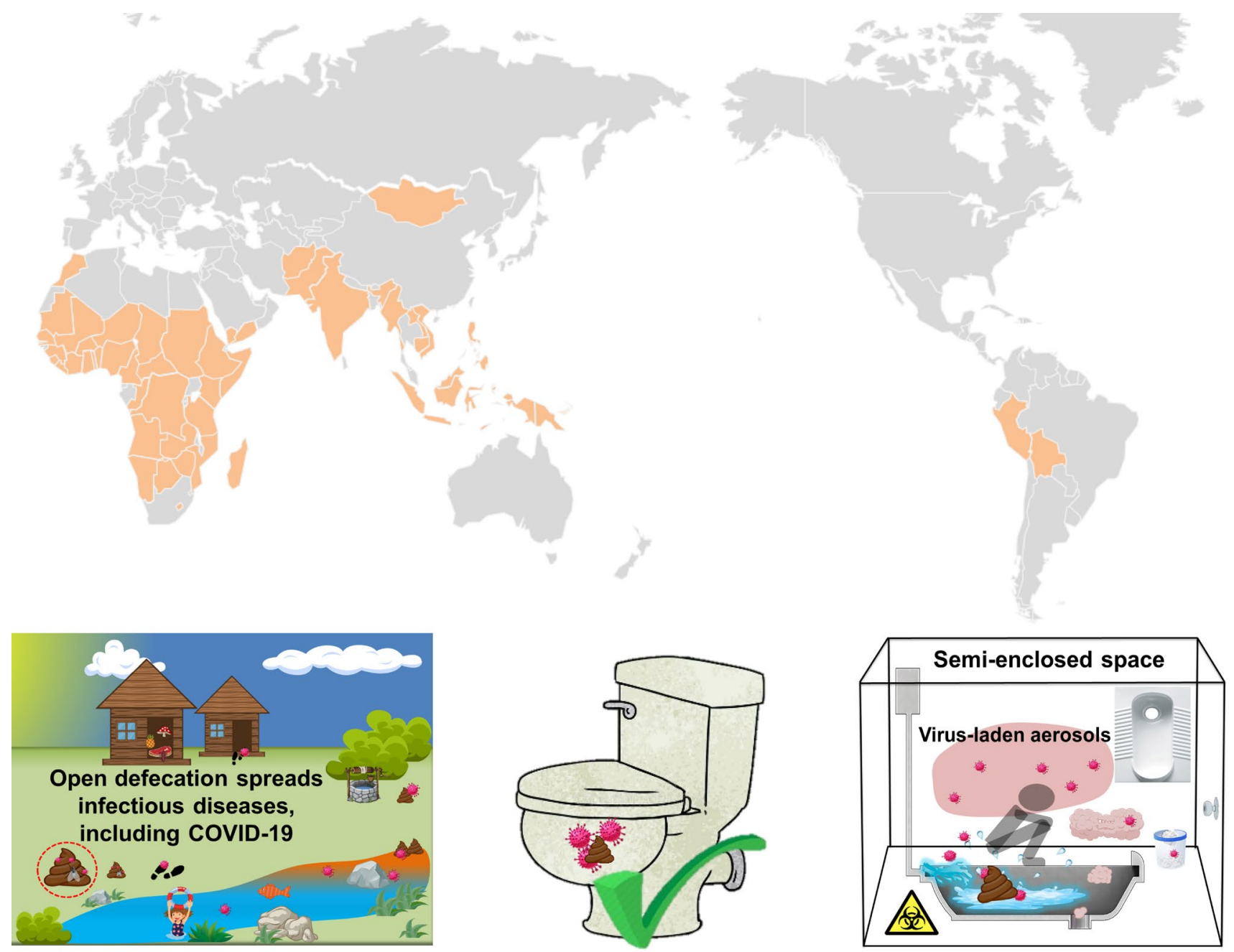

Fecal transmission of COVID-19 and other pathogens in developing communities

Fig. 1 According to a 2019 joint report by United Nation Children's Fund and the World Health Origination, there are 673 million people still defecating in the open and 1.3 billion people using limited or unimproved sanitation facilities (UNICEF and WHO 2019). Open defecation and the widespread usage of squat toilets pose additional risks on the transmission of COVID-19 and other fecal pathogens in developing communities. The practice of open defecation ena-

of sanitation facilities in developing communities. The federal government of India launched the "Swachh Bharat (Clean India)" campaign, which planned to build 110 million toilets and latrines between 2014 and 2019 (Regan and Suri 2019; Jain et al. 2020). In a similar effort, China launched the "toilet revolution" in 2015 to improve sanitation facilities for people living in rural areas (Cheng et al. 2018). The UNICEF (2018) set a long-term goal to end open defecation all over the world by 2030, although it admitted that more efforts would be required because progress in 37 countries was considered too slow to achieve this goal in due course. Table 1 lists the key data and findings from recent randomized surveys on the bles several potential pathways to transmit COVID-19 in these communities. Since squatting toilets typically have an open design with no lid or built-in U-trap, users may be easily exposed to virus-laden splashes and bioaerosols in the ambient air or surrounding surfaces when using squat toilets during the COVID-19 pandemic. The semienclosed space of squat toilets and lower breathing zone of users could exacerbate these risks

prevalence of open defecation in developing countries. Echoing with two previous studies (Bhatt et al. 2019; Vyas et al. 2019), the surveys suggested that the real situation of open defecation is likely to be underreported in those countries. Despite an increasing number of toilets and latrines, several factors have hindered efforts in eliminating this unhygienic practice, while population growth aggravated this problem (WHO 2019). Except for having no access to sanitation facilities, Bhatt et al. (2019) analyzed the subjective motivation of people practicing open defecation. Among the various factors identified, social convention, enjoyable open activity, and religion-related reasons all contributed to the choice of open defecation 


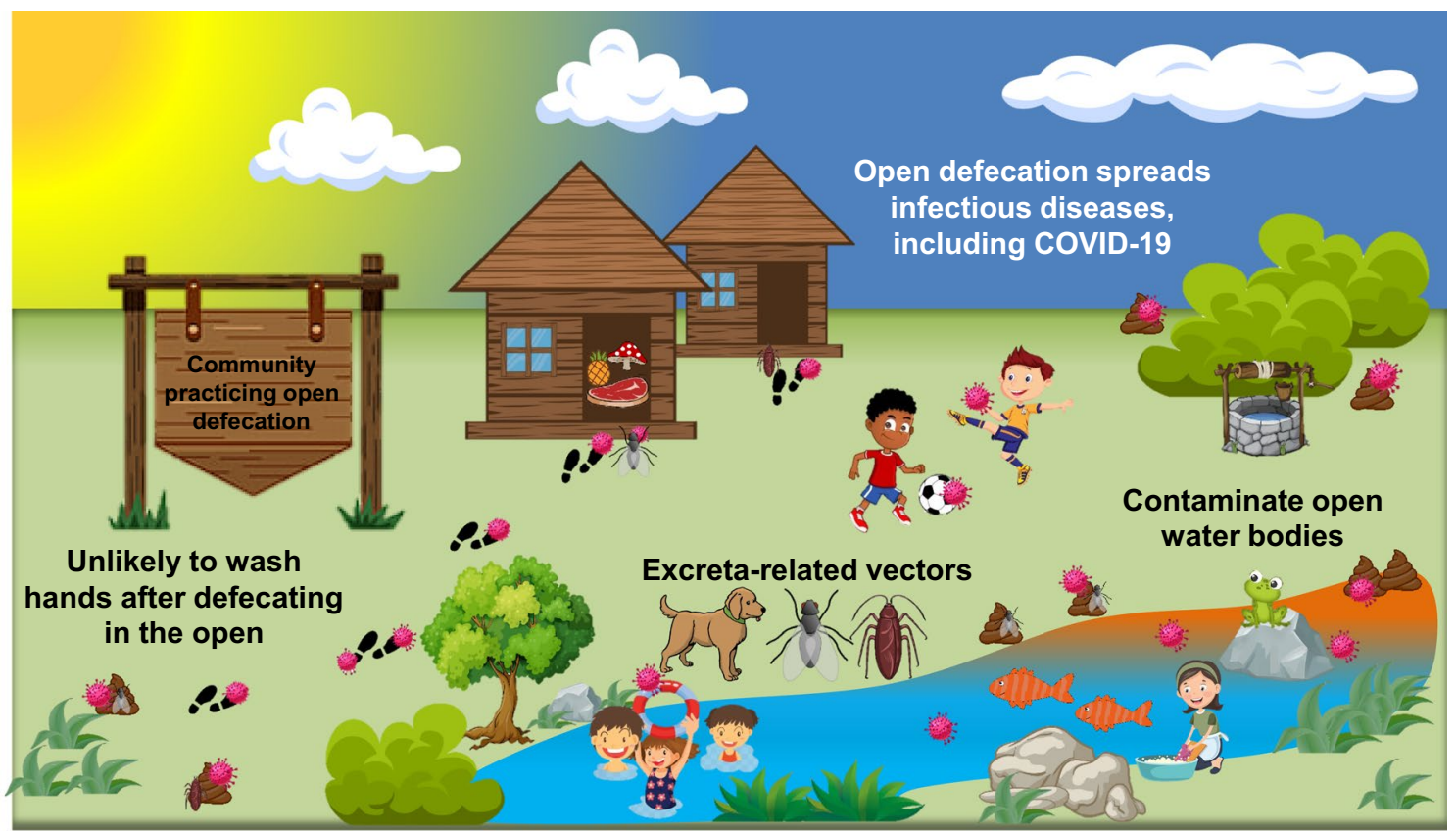

Fig. 2 Fecal-associated routes of COVID-19 transmission in communities with people practicing open defecation. Open defecation enables multiple routes of transmission for COVID-19 and other fecal pathogens, such as via contaminated shoes, objects, surfaces, and open water bodies due to inadequate hand hygiene after practicing open defecation, human outdoor activities, and excreta-related mechanical vectors
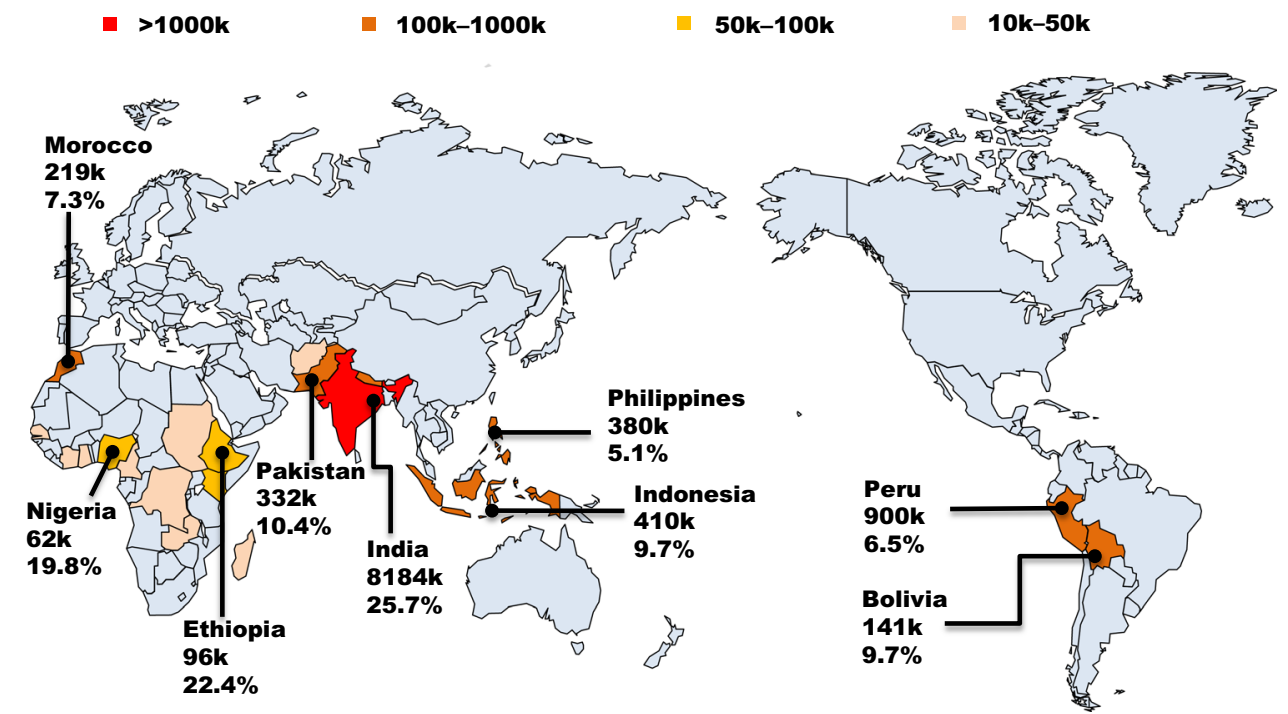

Fig. 3 Countries reporting large numbers of confirmed cases of COVID-19 infection and significant portions of their populations conventionally practicing open defecation. In communities having inadequate sanitary facilities and community-wide spread of COVID19 , human feces defecated in the open may become an additional

in those communities. Overall, ample evidence has shown that open defecation is a relatively common practice in developing communities, and risks of fecal-associated transmission of COVID-19 may arise from such contributor to the spread of the novel coronavirus in community environments. Open defecation dates and COVID-19 cases are based on the latest data by the World Health Origination (WHO, 2017b, 2020a). Data of COVID-19 cases are as of November 1, 2020

convention. To reduce these risks, it is of importance to promote awareness and take proper control measures in the COVID-19 pandemic, especially in places with high infection rates and significant populations conventionally 
Table 1 Key findings on the prevalence of open defecation in developing countries. n.a.: non applicable

\begin{tabular}{|c|c|c|c|c|}
\hline Country/region & Method & Sample size & Key data and findings & References \\
\hline Worldwide & Data statistics & n.a. & $\begin{array}{l}\text { At least } 20 \text { developing countries reported a significant portion of } \\
\text { their population practicing open defecation }(>5 \%)\end{array}$ & WHO (2017b) \\
\hline Worldwide & Data statistics & n.a. & $\begin{array}{l}\text { Progress of eliminating open defecation in } 37 \text { developing countries } \\
\text { before the year } 2030 \text { is quite slow }\end{array}$ & UNICEF (2018) \\
\hline Tanzania & Data analysis & Nationwide & $\begin{array}{l}\text { Despite the overall declined prevalence, open defecation is com- } \\
\text { mon in the Northeastern and lake regions in Tanzania }\end{array}$ & Maliti (2020) \\
\hline India & Random survey & 1216 households & The real situation of open defecation in India is underestimated & Vyas et al. (2019) \\
\hline India & Interviews & 21 individuals & $\begin{array}{l}\text { People have been aware of the risks associated with open defeca- } \\
\text { tion. However, challenges remain in constructing more latrines in } \\
\text { rural areas }\end{array}$ & Jain et al. (2020) \\
\hline Ethiopia & Questionnaire & 758 households & $\begin{array}{l}\text { The magnitude of diarrheal diseases in under-five children is } \\
\text { approximately twofold in communities practicing open defeca- } \\
\text { tion compared to those with no open defecation }\end{array}$ & Tafere et al. (2020) \\
\hline Ghana & Questionnaire & 367 households & $\begin{array}{l}\text { A multitude of factors including education, household size, occu- } \\
\text { pation, income, traditional norms, beliefs, and ownership of a } \\
\text { toilet facility have impacts on the choice of open defecation }\end{array}$ & Osumanu et al. (2020) \\
\hline Kenya & Questionnaire & 403 individuals & $\begin{array}{l}\text { The practice of open defecation is associated with the design, } \\
\text { structure, and conditions of latrines. About } 80 \% \text { of respondents } \\
\text { stated that the constructions of latrines have influences on their } \\
\text { choice of latrine use versus open defecation }\end{array}$ & Busienei et al. (2019) \\
\hline Nepal & Interviews & 20 individuals & $\begin{array}{l}\text { The choice of open defecation is not only dependent on the avail- } \\
\text { ability of sanitary latrines, but depends on personal preferences, } \\
\text { perceptions and religious beliefs. }\end{array}$ & Bhatt et al. (2019) \\
\hline
\end{tabular}

practicing open defecation. In the long term, provision of additional sanitary facilities should be associated with more efforts related to public education and communityled actions to end open defecation in these communities.

\section{Potential transmission modes of COVID-19 in squat toilets}

A significant portion of current sanitation facilities in developing communities are either unimproved or shared between households, which pose additional risks of virus transmission during the current pandemic. Sub-standard toilets are high-risk settings for cross-infection of fecal pathogens due to their often-inadequate ventilation and poor hygiene conditions. On June 29, 2020, the government of Beijing municipality reported two cases where two individuals were infected with SARS-CoV-2 after using a community public toilet (PGBM 2020). Li et al. (2020) investigated the aerosols ("plumes") generated by flushing toilets and their influences on virus transmission. When users flush their toilets, water rushes into the bowl and quickly expels the air, creating strong turbulences with a maximum upward velocity at 5 $\mathrm{m} / \mathrm{s}$. These can carry splashes and bioaerosols far out of the toilet bowl and result in a large area spread. Fluid dynamics simulation showed that the two-phase flow could rise to $106.5 \mathrm{~cm}$ above the toilet at a velocity of $0.3-0.4 \mathrm{~cm} / \mathrm{s}$.
Toilet plumes not only contaminate the surrounding surfaces but may promote the transmission of fecal pathogens.

During the COVID-19 episode, the WHO suggested toilet users to put the lid down before flushing, as a precautionary measure to prevent transmission via virus-contaminated splashes, droplets, and aerosols (WHO 2020c). Such a simple task, however, may prove rather difficult for people in developing communities. Unlike the lidded closestools with built-in U-traps often found in Western homes, openflushing squat toilets are extremely common in developing countries (Fig. 4), including places with improved sanitary facilities (ASEAN 2012; Sun and Han 2020). Although no study has been reported to date, users of squat toilets are likely to face elevated risks of fecal transmission during the COVID-19 pandemic, especially in facilities shared between different households or places with high foot traffic.

The lidless design of squatting pans leads to flushing in an open manner, where the surrounding surfaces (e.g., footsteps) and ambient air can be easily contaminated by human fecal matter and urine. When squat toilets are flushed, water gushes down from the cistern and collides with fresh human excreta in the open toilet bowl, generating splashes and aerosols that can be easily contaminated by fecal matter and urine (Fig. 5). Evidence was shown in an earlier study that mean fecal coliform counts on top of squatting pans in Cambodia homes were 21-fold higher than those found on western-style closestool toilets in the USA (Sinclair and Gerba 2011). Mahdavinejad et al. (2011) investigated the 
Fig. 4 Squat toilets in different geographic regions. (a) A toilet cubicle for public access at the author's affiliation in Xi'an, China; (b) residual feces left in the bowl of a squat toilet after flushing. Footsteps were easily contaminated by splashes containing fecal matter and urine during open flushing; (c) users were accustomed to dispose of their used tissues and feminine hygiene products in the open waste bin; (d) a squat toilet in India showing a similar design to those seen in China. Reprinted with a Creative Commons CC-BY license from Elsevier (Welling et al., 2020); (e) a squat toilet used in Africa (Photograph credit: P. Marion/Getty Images, available at: www.tripsavvy.com/howto-use-a-squat-toilet-1454333); (f) a toilet for public access in a traditional coffee shop ("kopitiam") in Malaysia (Photograph credit: www.travelblog.org/ Photos/7083239)

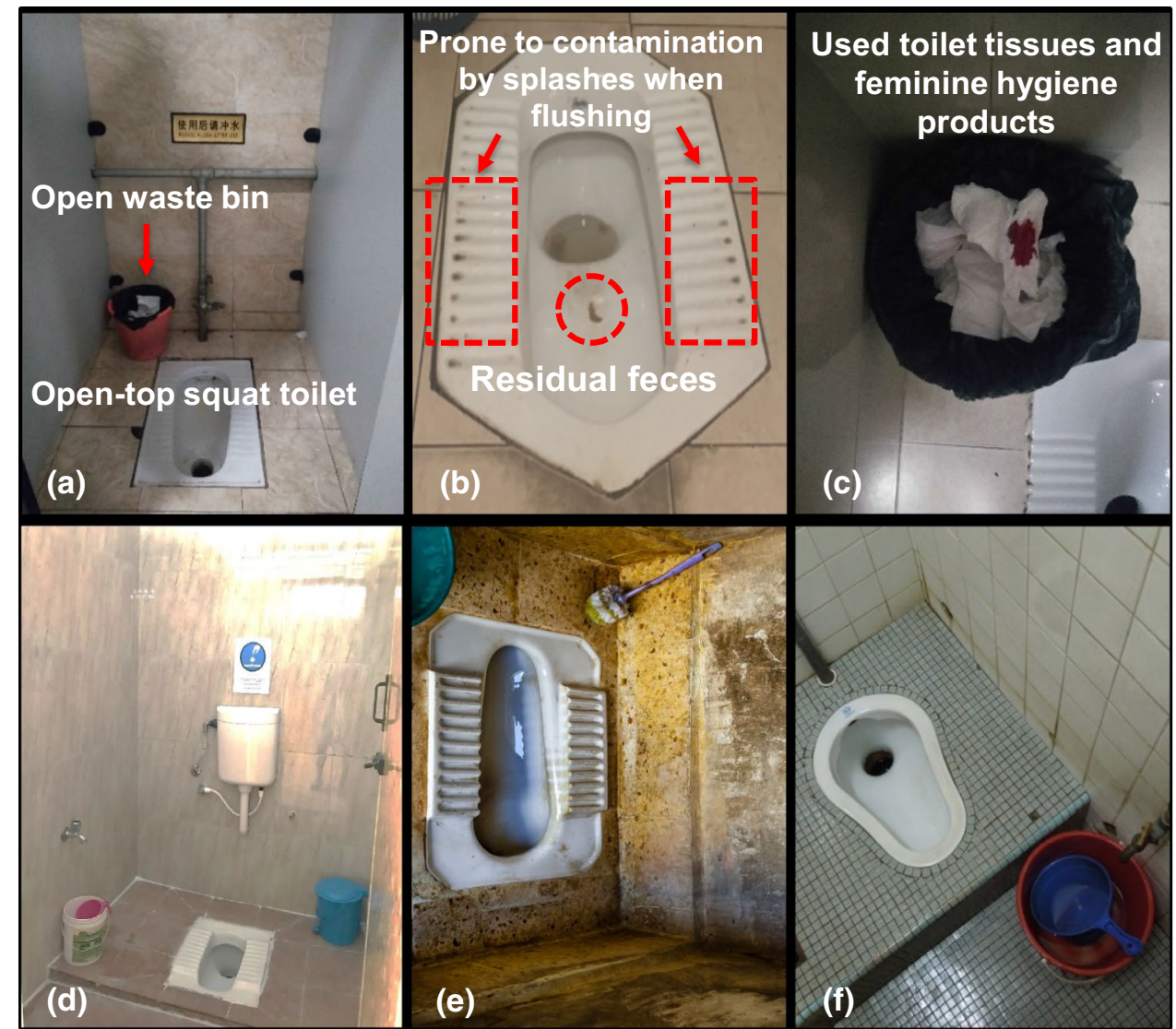

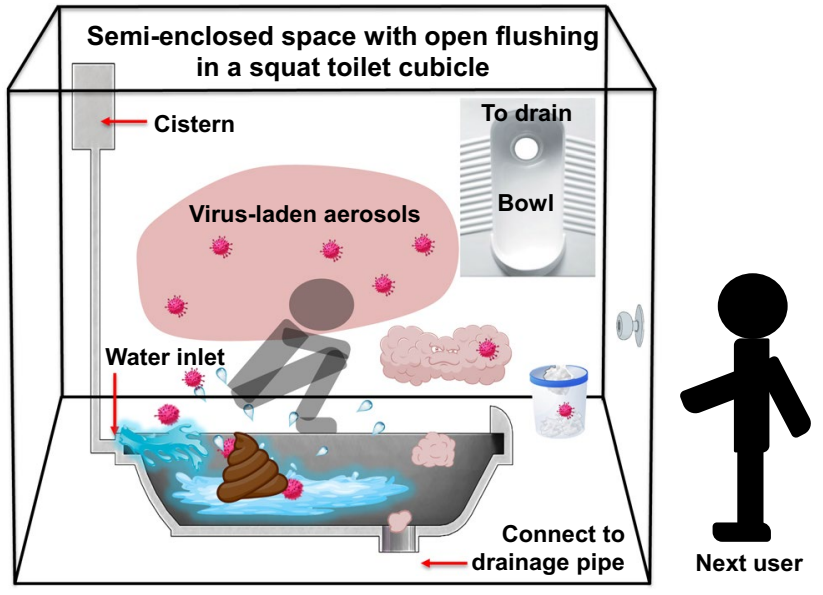

Fig. 5 Potential transmission modes of COVID-19 in a squat toilet. Human feces and urine drop into the open bowl of the squat toilet. When flushed, water from the cistern rushes down rapidly into the bowl, collides with feces, and carries these into the drain through the outlet. Large amounts of splashes and aerosols, which are likely to be contaminated with fecal matter and urine, are generated in this process, and can spread viruses onto the surrounding surfaces and into the ambient air in the semi-enclosed toilet cubicle. Since most squat pans do not have U-traps to block uprising airflows, aerosols can easily rise from the drainage pipe through the open outlet. The squatting posture significantly lowers the breathing zone of toilet users, who may inhale virus-laden aerosols generated from prior flushing or rising from the drainage pipe connected below conditions of 40 toilets ( 20 closestools and 20 squat pans) in Iran after one year of use. Although there was no significant difference in the types of microorganisms present on the two types of toilets, the latter showed higher loadings of bacterial pathogens on their surfaces. An additional risk factor lies in the fact that the squatting posture significantly lowers the breathing zone of toilet users, which moves closer to the open toilet bowl and directly above the bottom drain. This may increase their risks of inhaling droplets and aerosols in the ambient air after flushing or even those rising from the drainage pipe. Since most squat pans do not have integrated U-traps, water sealing is often not possible to prevent uprising flows of sewage droplets or aerosols from drainage pipes or sewers they are connected into. Virus-laden aerosols may rise from the drains due to flushing activities of other toilets connected to the same drainage pipe, which was the direct cause of a large community outbreak during the 2003 SARS epidemic (Yu et al. 2004). Due to the prevalence of unflushable products in use, open waste bins are often placed in squat toilets to collect used toilet tissues and feminine hygiene products to prevent blockage in drains and downstream sewers. These present an additional source of virus transmission for custodial staff or toilet users themselves, especially in public places such as schools, hospitals, and airports (Sun and Han 2020; Welling et al. 2020). 
Overall, the existing evidence shows that squat toilets are extensively used in developing countries and pose elevated risks of COVID-19 transmission due to their lidless design, open flushing mechanism, and lowered breathing zone of toilet users. Given their widespread use in developing communities, it is important for users to take precautions in these high-risk settings during the current pandemic. Where possible, reducing the use of lidless squatting pans, cleaning up used issues and hygiene products from open waste bins in time, and maintaining natural ventilation are effective methods to reduce the risk of virus transmission in the current pandemic. In particular, users of squat toilets should pay special attention to protecting themselves from inhaling virus-laden splashes and aerosols. In the longer term, improved designs such as lidded toilets and integrated U-traps could be considered for reducing the transmission of fecal pathogens in toilets used in developing communities.

\section{Conclusion}

Fecal-associated transmission has been identified as a potential route of virus spread in the COVID-19 pandemic, as an increasing body of evidence confirmed high viral loadings and infectivity of SARS-CoV-2 in patients' stools, including asymptomatic, pre-symptomatic, and convalescent individuals. While governments and regulatory bodies have taken actions to control the spread, the reality is that a significant portion of the population in developing communities do not have access to safe and private sanitary facilities, and thus face elevated risks of exposure to fecal pathogens, including SARS-CoV-2. Existing evidence and scholarly discussions indicate that open defecation is a relatively common practice in many developing countries, which can be hardly eliminated in a short term due to the complex driving factors such as the lack of sanitary facilities, personal preferences, and religious beliefs. There are at least twenty countries where a $5-26 \%$ of their population conventionally practice open defecation while reporting more than 10,000 confirmed COVID-19 infections. In these communities, the presence of human wastes in the open environment is an ongoing threat of virus spread during the current pandemic, where the transmission of fecal pathogens, including COVID-19, can be effectuated via various environmental routes. Another important but neglected risk is the prevalence of squat toilets in developing countries. Earlier studies have shown that squat toilets have higher pathogen loadings on their surrounding surfaces compared with western-style closestool toilets in similar service conditions. Due to the common lidless design, open flushing mechanism, and absence of integrated U-traps, flushing of squat toilets can generate large amounts of bioaerosols and splashes, potentially exposing users to fecal pathogens and contaminating the ambient air and surrounding surfaces, which all contribute to the transmission of COVID-19 and other fecal pathogens, especially in high turnover squat toilets or those shared between different households. Overall, we propose that public health authorities and international aid organizations should focus more on these area-specific transmission routes, by raising public awareness and providing necessary aids to mitigate such risks in these communities. Particularly, future actions should not only focus on infrastructure but paying more attention to public education and community-led actions to reduce the practices of open defecation, while in the longer term, improved designs and mitigation measures should be put into practice to reduce the spread of fecal pathogens associated with the use of squat toilets. While the COVID19 pandemic makes these imperative, fecal transmission of human pathogens is an ongoing public health threat, and the provision of access to improved sanitary facilities should be included as a priority in their long-term community development plan.

Acknowledgements This work was funded by the "Young Talent Support Plan” of Xi' an Jiaotong University.

\section{Compliance with ethical standards}

Conflict of interest The authors declare that they have no conflict of interest in this work.

\section{References}

ASEAN (2012) Association of Southeast Asian Nations. ASEAN public toilet standard. https://www.asean.org/wp-content/uploa ds/2012/05/ASEAN-Public-Toilet-Standard.pdf. Accessed 12 Nov 2020

Bhatt N, Budhathoki SS, Lucero-Prisno DE, Shrestha G, Bhattachan M, Thapa J, Sunny AK, Upadhyaya P, Ghimire A, Pokharel PK (2019) What motivates open defecation? A qualitative study from a rural setting in Nepal. PLoS ONE 14(7):e0219246. https://doi. org/10.1371/journal.pone.0219246

Busienei PJ, Ogendi GM, Mokua MA (2019) Latrine structure, design, and conditions, and the practice of open defecation in Lodwar town, Turkana county, Kenya: A quantitative methods research. Turkana county, Kenya. https://doi.org/10.1177/1178630219 887960

Caruso BA, Freeman MC (2020) Shared sanitation and the spread of COVID-19: risks and next steps. Lancet Planet Health 4(5):E173. https://doi.org/10.1016/S2542-5196(20)30086-3

Cheng S, Li Z, Uddin SMN, Mang H, Zhou X, Zhang J, Zheng L, Zhang L (2018) Toilet revolution in China. J Environ Manag 216:347-356. https://doi.org/10.1016/j.jenvman.2017.09.043

Dai H, Han J, Lichtfouse E (2020) Who is running faster, the virus or the vaccine? Environ Chem Lett 18:1761-1766. https://doi. org/10.1007/s10311-020-01110-w

Dehghani R, Kassiri H (2020) A brief review on the possible role of house flies and cockroaches in the mechanical transmission of Coronavirus Disease 2019 (COVID-19). Arch Clin Infect Dis 15:e102863. https://doi.org/10.5812/archcid.102863 
Gu J, Han B, Wang J (2020) COVID-19: gastrointestinal manifestations and potential fecal-oral transmission. Gastroenterol 158(6):15181519. https://doi.org/10.1053/j.gastro.2020.02.054

Guerrant RL, DeBoer MD, Moore SR, Scharf RJ, Lima AAM (2013) The impoverished gut-a triple burden of diarrhoea, stunting and chronic disease. Nat Rev Gastroenterol Hepatol 10(4):220-229. https://doi.org/10.1038/nrgastro.2012.239

Han J, He S (2020) Need for assessing the inhalation of micro(nano) plastic debris shed from masks, respirators, and home-made face coverings during the COVID-19 pandemic. Environ Pollut 268:115728. https://doi.org/10.1016/j.envpol.2020.115728

Han J, Zhang X, He S, Jia P (2020) Can the coronavirus disease be transmitted from food? A review of evidence, risks, policies and knowledge gaps. Environ Chem Lett. https://doi.org/10.1007/ s10311-020-01101-x

Heller L, Mota CR, Greco DB (2020) COVID-19 faecal-oral transmission: are we asking the right questions? Sci Total Environ 729:138919. https://doi.org/10.1016/j.scitotenv.2020.138919

IOGMPG (2020) Information Office of Guangzhou Municipal People's Government. 125th of Press conference on COVID19 cases, prevention and control. https://m.dayoo.com/16043 3.shtml. Accessed 12 Nov 2020

Jain A, Wagner A, Snell-Rood C, Ray I (2020) Understanding Open Defecation in the Age of Swachh Bharat Abhiyan: agency, Accountability, and Anger in Rural Bihar. Int J Environ Res Public Health 17(40):1384. https://doi.org/10.3390/ijerph1704 1384

Jeong HW, Kim S, Kin Y, Kin JH, Cho YJ, Kin S, Kang H, Kim S, Park S, Kim E, Choi YK (2020) Viable SARS-CoV-2 in various specimens from COVID-19 patients. Clin Microbiol Infect. https://doi.org/10.1016/j.cmi.2020.07.020

Li Y, Wang J, Chen X (2020) Can a toilet promote virus transmission? From a fluid dynamics perspective. Phys Fluids 32(6):065107. https://doi.org/10.1063/5.0013318

Mahdavinejad M, Bemanian M, Farahani SF, Tajik A (2011) Role of toilet type in transmission of infections. Acad Res Int 1 (2): http://www.savap.org.pk/journals/ARInt./Vol.1(2)/2011(1.211).pdf. Accessed 12 Nov 2020

Maliti E (2020) Evolution of open defecation prevalence in Tanzania 2002-2015: evidence from national demographic and health surveys. Dev Pract. https://doi.org/10.1080/09614 524.2020 .1828283

Morawska L, Milton DK (2020) It is time to address airborne transmission of COVID-19. Clin Infect Dis. https://doi.org/10.1093/ $\mathrm{cid} / \mathrm{ciaa} 939$

Olusola-Makinde OO, Reuben RC (2020) Ticking bomb: prolonged faecal shedding of novel coronavirus (2019-nCoV) and environmental implications. Environ Pollut. https://doi.org/10.1016/j. envpol.2020.115485

Osumanu IK, Kosoe EA, Ategeeng F (2020) Determinants of open defecation in the Wa municipality of Ghana: empirical findings highlighting sociocultural and economic dynamics among households. J Environ Public Health. https://doi.org/10.1155/2019/3075840

Paital B, Agrawal PK (2020) Air pollution by $\mathrm{NO}_{2}$ and $\mathrm{PM}_{2.5}$ explains COVID-19 infection severity by overexpression of angiotensinconverting enzyme 2 in respiratory cells: a review. Environ Chem Lett https://doi.org/10.1007/s10311-020-01091-w

PGBM (2020) People's Government of Beijing Municipality. Press conference on COVID-19 cases, prevention and control. http:// www.beijing.gov.cn/shipin/Interviewlive/274.html. Accessed 12 Nov 2020

Regan H, Suri M (2019) CNN News. Half of India couldn't access a toilet 5 years ago. Modi built $110 \mathrm{M}$ latrines-but will people use them? https://edition.cnn.com/2019/10/05/asia/india-modi-opendefecation-free-intl-hnk-scli/index.html. Accessed 12 Nov 2020
Rytter MJH, Kolte L, Briend A, Friis H, Christensen VB (2014) The immune system in children with malnutrition-A systematic review. PLoS One 9(8):e105017. https://doi.org/10.1371/journ al.pone. 0105017

Setti L, Passarini F, Gennaro GD, Barbieri P, Perrone MG, Borelli M, Palmisani J, Gilio AD, Torboli V, Fontana F, Clemente L, Pallavicini A, Ruscio M, Piscitelli P, Miani A (2020) SARS-Cov-2 RNA found on particulate matter of Bergamo in Northern Italy: first evidence. Environ Res 188:109754. https://doi.org/10.1016/j. envres.2020.109754

Sharma VK, Jinadatha C, Lichtfouse E (2020) Environmental chemistry is most relevant to study coronaviruspandemics. Environ Chem Lett 18:993-996. https://doi.org/10.1007/s10311-020-01017-6

Sinclair RG, Gerba CP (2011) Microbial contamination in kitchens and bathrooms of rural Cambodian village households. Lett Appl Microbiol 52(2):144-149. https://doi.org/10.1111/j.1472765X.2010.02978.x

Stewart CP, Iannotti L, Dewey KG, Michaelsen KF, Onyango AW (2013) Contextualising complementary feeding in a broader framework for stunting prevention. Matern Child Nutr 9:27-45. https://doi.org/10.1111/mcn.12088

Sun J, Zhu A, Li H et al (2020) Isolation of infectious SARS-CoV-2 from urine of a COVID-19 patient. Emerg Microbes Infect 9(1):991-993. https://doi.org/10.1080/22221751.2020.1760144

Sun S, Han J (2020) Unflushable or missing toilet paper, the dilemma for developing communities during the COVID-19 episode. Environ Chem Lett. https://doi.org/10.1007/s10311-020-01064-z

Tafere Y, Abate BA, Enyew HD, Mekonnen AB (2020) Diarrheal diseases in under-five children and associated factors among Farta district rural community, Amhara regional state, north central Ethiopia: a comparative cross-sectional study. J Environ Public Health. https://doi.org/10.1155/2020/6027079

UNICEF and WHO (2019) United Nation Children's Fund and World Health Organization, 2019. Progress on household drinking water, sanitation and hygiene 2000-2017: Special focus on inequalities. https://www.who.int/water_sanitation_health/publications/jmpreport-2019/en/. Accessed 12 Nov 2020

UNICEF (2018) United Nation Children's Fund. UNICEF's game plan to end open defecation. https://www.unicef.org/wash/files/UNICE F_Game_plan_to_end_open_defecation_2018.pdf. Accessed 12 Nov 2020

Usman M, Farooq M, Hanna K (2020) Existence of SARS-CoV-2 in wastewater: implications for its environmental transmission in developing communities. Environ Sci Technol 54(13):7758-7759. https://doi.org/10.1021/acs.est.0c02777

Vyas S, Srivastav N, Mary D, Goel N, Srinivasan S, Tannirkulam A, Ban R, Spears D, Coffey D (2019) Measuring open defecation in India using survey questions: evidence from a randomised survey experiment. BMJ Open 9(9):e030152. https://doi.org/10.1136/ bmjopen-2019-030152

Wang LQ, Li MY, Yu S et al (2020a) Unexpected rise of ozone in urban and rural areas, and sulfur dioxide in rural areas during the coronavirus city lockdown in Hangzhou, China: implications for air quality. Environ Chem Lett. https://doi.org/10.1007/s1031 1-020-01028-3

Wang X, Han J, Lichtfouse E (2020b) Unprotected mothers and infants breastfeeding in public amenities during the COVID-19 pandemic. Environ Chem Lett 18:1447-1450. https://doi.org/10.1007/s1031 1-020-01054-1

Welling CM, Varigala S, Krishnaswamy S, Raj A, Lynch B, Piascik JR, Stoner BR, Hawkins BT, Hegarty-Craver M, Luettgen MJ, Grego $S$ (2020) Resolving the relative contributions of cistern and pour flushing to toilet water usage: measurements from urban test sites in India. Sci Total Environ 730:138957. https://doi.org/10.1016/j. scitotenv.2020.138957 
WHO (2020a) World Health Organization (WHO). Coronavirus disease (COVID-19) pandemic-numbers at a glance. https://www. who.int/emergencies/diseases/novel-coronavirus-2019. Accessed 12 Nov 2020

WHO (2020b) World Health Organization. Advice on the use of masks in the context of COVID-19: interim guidance. https://apps.who. int/iris/bitstream/handle/10665/332293/WHO-2019-nCov-IPC Masks-2020.4-eng.pdf. Accessed 12 November 2020

WHO (2020c) World Health Organization. Water, sanitation, hygiene, and waste management for the COVID-19 virus. https://apps. who.int/iris/bitstream/handle/10665/333560/WHO-2019-nCoVIPC_WASH-2020.4-eng.pdf. Accessed 12 Nov 2020

WHO (2019) World Health Organization. Sanitation. https://www. who.int/news-room/fact-sheets/detail/sanitation. Accessed 12 Nov 2020

WHO (2017a) World Health Organization. Diarrhoeal disease. https ://www.who.int/news-room/fact-sheets/detail/diarrhoeal-disease. Accessed 12 Nov 2020
WHO (2017b) World Health Organization. World Health Data Platform - Population practising open defecation (\%). https://www.who.int/ data/gho/data/indicators/indicator-details/GHO/population-pract ising-open-defecation. Accessed 12 Nov 2020

Xiao F, Sun J, Xu Y, Li F, Huang X, Li H, Zhao J, Huang J, Zhao J (2020) Infectious SARS-CoV-2 in feces of patient with severe COVID-19. Emerg Infect Dis 26(8):1920-1922. https://doi. org/10.3201/eid2608.200681

Yu ITS, Li Y, Wong TW, Tam W, Chan AT, Lee JHW, Leug DYC, Ho $\mathrm{T}$ (2004) Evidence of airborne transmission of the severe acute respiratory syndrome virus. N Engl J Med 350(17):1731-1739. https://doi.org/10.1056/NEJMoa032867

Publisher's Note Springer Nature remains neutral with regard to jurisdictional claims in published maps and institutional affiliations. 